Research Article

\title{
Knowledge, Attitude and Practice towards COVID- 19 among Social Media Users in an Engineering College, South India
}

\author{
Vishnu Priya', $\underline{\text { Samyuktha }}{ }^{2}$, Sharon Fernandez ${ }^{3}, \underline{\text { Arun Biju }}^{4}, \underline{\text { Anand GS }}^{5}, \underline{\text { Vaibhav Venniyoor }}^{6}$, \\ Kathleen Anne Mathew ${ }^{7}$, Vishal Marwaha ${ }^{8}$ \\ 1,2,3,4,5 III MBBS (Part-I) Student, ${ }^{6}$ House Surgeon, ${ }^{8}$ Principal, Amrita School of Medicine, Amrita Institute of Medical Sciences, \\ Amrita Vishwa Vidyapeetham, Kochi, Kerala, India. \\ ${ }^{7}$ Senior Resident, Department of Psychiatry, Amrita Institute of Medical Sciences, Amrita Vishwa Vidyapeetham , Kochi, Kerala, \\ India.
}

DOI: https://doi.org/10.24321/0019.5138.202123

\section{I $\quad \mathbf{N} \quad \mathbf{F} \quad \mathbf{O}$}

\author{
Corresponding Author: \\ Kathleen Anne Mathew, Department of Psychiatry, \\ Amrita Institute of Medical Sciences, Amrita \\ Vishwa Vidyapeetham, Kochi, Kerala, India. \\ E-mail Id: \\ kathymathew@gmail.com \\ Orcid Id: \\ https://orcid.org/0000-0001-7089-1409 \\ How to cite this article: \\ Priya V, Samyuktha S, Fernandez S, Biju A, \\ Anand GS, Venniyoor V, Mathew KA, Marwaha \\ V. Knowledge, Attitude and Practice towards \\ COVID-19 among Social Media Users in an \\ Engineering College, South India. J Commun \\ Dis. 2021; 53(2): 35-42.
}

Date of Submission: 2021-02-23

Date of Acceptance: 2021-06-23

\section{$\begin{array}{llllllll}\mathbf{A} & \mathbf{B} & \mathbf{S} & \mathbf{T} & \mathbf{R} & \mathbf{A} & \mathbf{C} & \mathbf{T}\end{array}$}

Background: COVID-19 pandemic has been affecting the global health system profoundly. Various measures have been taken to contain the disease spread. This study was conducted with the aim of assessing the knowledge, attitude and practices in relation to COVID-19 in social media users among college-going students.

Methods: A cross -sectional web-based study was conducted among the students of an engineering college in south India. The study questionnaire was adapted from an earlier study which included four segments to collect information regarding socio-demographic details, knowledge, attitude and practices regarding COVID-19. Descriptive statistics was employed and the results were expressed as numbers and percentages.

Results: A total of 252 engineering students took part in the study. 251 participants (99.6\%) had knowledge about the symptoms of COVID-19 and 243 (96.4\%) participants knew the methods of transmission of the virus. With regard to the attitude towards COVID-19, 246 (97.6\%) individuals felt that taking adequate precautions will reduce disease transmission, and $179(71.0 \%)$ individuals completely agreed with the government's decision to implement the lockdown. Regarding practices related to COVID-19, 214 (84.9\%) individuals regularly disinfected their hands, 249 (98.8\%) respondents wore a mask regularly, and 226 (89.7\%) participants adhered to social distancing norms.

Conclusion: The respondents in this study who were social media users in an engineering college in south India had fairly good knowledge, displayed a positive attitude and followed responsible practices with regard to COVID-19. Promotion of knowledge and awareness about the right practices related to COVID-19 among the public is necessary to ensure the adoption of effective preventive behaviours.

Keywords: CoviD-19, Knowledge, Attitude, Practices, College Students 


\section{Introduction}

A novel strain of coronavirus (SARS-CoV-2) was first detected in December 2019 in Wuhan, China after an outbreak of pneumonia of unknown etiology raised an alarm internationally. ${ }^{1}$ The virus has now spread to over 218 countries around the world and the World Health Organization has declared it a "pandemic". ${ }^{2} 174,654,044$ individuals world-wide have been afflicted with COVID-19 and among these, 157,965,654 individuals have recovered while it has been fatal for $3,759,793$ as per the latest data. ${ }^{3}$ In India, the first COVID-19 case was reported in Kerala on January $30,2020 .{ }^{4}$ The spread has accentuated rapidly to a scenario of 2,642,9395 confirmed cases, 1,47,830 active cases, and 10,157 fatalities in Kerala alone as of June $8,2021 .{ }^{5}$ It is vital that every individual understands the immensity of this pandemic. Therefore, public awareness and adherence to preventive measures play a major role in managing a crisis of this vastness. ${ }^{6}$ Kerala has earned global repute for the 'Break the Chain' campaign and community education focusing on physical distancing, hand washing and using face masks. ${ }^{4}$ Public enforcement, which is influenced by their Knowledge, Attitude and Practices (KAP) towards COVID-19, is essential for such initiatives to be successful. ${ }^{7}$ There are only a limited number of studies on KAP towards COVID-19 that have been conducted in south India. KAP surveys collect information on what is known, believed, and done by a specific population. It provides information on the readiness of the society to accept the changes in behaviour imposed by the healthcare authorities which also helps to determine the type of intervention that would help to change misconceptions about the virus. ${ }^{8}$

This study was conducted in an engineering college in south India. The young students pursuing their professional degree might have a significant influence on the health and well-being of their families and friends. Furthermore, this population tends to be the maximum socially active group, both on social media and outside in the community. Hence their attitude and perceptions would have an impact on spread of COVID-19 pandemic. At the time of this study, public spaces were mostly visited by young adults as the colleges were still closed and online classes were implemented. ${ }^{10}$ Considering the fact that these students have consistent access to the information regarding COVID-19 through online platforms, it is essential to assess if due attention is paid in understanding and adopting the guidelines issued.

\section{Materials and Methods}

Study Design: This was a cross-sectional study conducted through an online questionnaire-based survey.

Inclusion and Exclusion criteria: All students enrolled in an engineering college in south India were included in the study.

Study Population, Area and Period: The target participants of the study were the active social media users in an engineering college in south India. After obtaining approval from the Institutional Ethics Committee, the study was commenced. Data was collected over a period of four days.

Sample Size Determination: Based on the proportion of overall knowledge, attitude and practices about COVID-19 among social media users in Jammu and Kashmir (61\%) observed in an earlier publication ${ }^{9}$ and with $10 \%$ allowable error and $95 \%$ confidence interval, the minimum sample size came up to 245 for this study.

\section{Sampling Technique}

Purposive sampling technique was employed to obtain data from among students enrolled in an engineering college in south India. 252 students enrolled in the college who were social media users gave informed consent to participate in the study.

\section{Study Questionnaire}

The structured questionnaire used for this study was adapted from an earlier study conducted in a northern state of India. ${ }^{9}$ Written permission was obtained from the authors after which necessary changes in language, style, and responses were done for the current study. This questionnaire included questions for gathering data on socio-demographic particulars, COVID-19 related knowledge, attitude, and practices in four different segments.

Data Collection: The study data was collected using an online survey through Google Forms. Course-specific WhatsApp groups were identified, and the study questionnaire was shared with the group members.

\section{Statistical Analysis}

Descriptive statistics was employed in this study to summarise the responses regarding knowledge, attitude and practice toward COVID-19. Variables were summarised as frequency and percentage. All analyses were done using Microsoft Excel 2016.

\section{Results}

\section{Socio-demographic Characterististics}

Out of the total of 252 respondents, 158 (62.7\%) were male and $94(37.3 \%)$ were female. Majority (62.7\%) were in the age group of $18-40$ years. 87 (34.5\%) participants were second-year students, 81 (32.1\%) were final year students, 62 (24.6\%) were second-year students, and 22 (8.7\%) were first-year students. 161 (63.9\%) respondents resided in urban areas while $91(36.1 \%)$ resided in rural areas. 121 (48\%) study participants reported having one or two family members aged above 60 years (Table 1 ).

Knowledge of the Study Participants on COVID- 19

All the study participants answered that they were aware 
about COVID-19. 243 (96.4\%) participants knew all the modes of transmission of this disease, and 177 (70.2\%) respondents knew how to protect themselves from being infected. 251 (99.6\%) participants were aware of the symptoms of the illness. 197 (78.2\%) individuals knew the dedicated helpline number of the state. 237 (94\%) respondents used newspapers, televisions, and social media to gain knowledge about COVID-19 (Table 2).

Table I.Socio-demographic Characteristics of the Study Participants $(n=252)$

\begin{tabular}{|c|c|}
\hline Characteristics & $\begin{array}{l}\text { Frequency } \\
\text { (\%) }\end{array}$ \\
\hline \multicolumn{2}{|l|}{ Age group (years) } \\
\hline$<18$ & $94(37.3)$ \\
\hline $18-40$ & $158(62.7)$ \\
\hline \multicolumn{2}{|l|}{ Gender } \\
\hline Female & $94(37.3)$ \\
\hline Male & $158(62.7)$ \\
\hline \multicolumn{2}{|l|}{ Year } \\
\hline 1st year & $22(8.7)$ \\
\hline 2nd year & $87(34.5)$ \\
\hline 3rd year & $62(24.6)$ \\
\hline 4th year & $81(32.1)$ \\
\hline \multicolumn{2}{|l|}{ Region } \\
\hline East India & $2(0.8)$ \\
\hline North India & $4(1.6)$ \\
\hline Northeast India & $2(0.8)$ \\
\hline South India & $239(94.8)$ \\
\hline Western India & $4(1.6)$ \\
\hline Central India & $1(0.4)$ \\
\hline \multicolumn{2}{|l|}{ Residence } \\
\hline Rural & $91(36.1)$ \\
\hline Urban & $161(63.9)$ \\
\hline \multicolumn{2}{|c|}{ Number of family members } \\
\hline$<3$ & $10(4.0)$ \\
\hline $3-5$ & $211(83.7)$ \\
\hline $6-8$ & $26(10.3)$ \\
\hline$>8$ & $5(2.0)$ \\
\hline \multicolumn{2}{|c|}{$\begin{array}{l}\text { Number of family members above the } \\
\text { age of } 60\end{array}$} \\
\hline 0 & $122(48.4)$ \\
\hline $1-2$ & $121(48.0)$ \\
\hline $3-4$ & $6(2.4)$ \\
\hline$>4$ & $3(1.2)$ \\
\hline
\end{tabular}

Table 2.Knowledge regarding COVID- 19 among Study Participants $(n=252)$

\begin{tabular}{|c|c|}
\hline Knowledge & Frequency (\%) \\
\hline \multicolumn{2}{|l|}{ Do you know about COVID-19? } \\
\hline Yes & $252(100)$ \\
\hline No & $0(0)$ \\
\hline \multicolumn{2}{|l|}{$\begin{array}{l}\text { Where did you first hear about } \\
\text { COVID-19? }\end{array}$} \\
\hline Newspaper & $27(10.7)$ \\
\hline Others (NGO/announcements) & $11(4.4)$ \\
\hline Social media & $150(59.5)$ \\
\hline TV & $64(25.4)$ \\
\hline \multicolumn{2}{|l|}{$\begin{array}{l}\text { Where was the first case of } \\
\text { COVID-19 reported in? }\end{array}$} \\
\hline China & $250(99.2)$ \\
\hline India & $2(0.8)$ \\
\hline Saudi & $0(0)$ \\
\hline Italy & $0(0)$ \\
\hline \multicolumn{2}{|l|}{ How does COVID-19 transmit? } \\
\hline$<1 \mathrm{~m}$ distance & $3(1.2)$ \\
\hline Touch & $1(0.4)$ \\
\hline Sneezing & $5(2.0)$ \\
\hline All of the above & $243(96.4)$ \\
\hline \multicolumn{2}{|l|}{$\begin{array}{c}\text { Do you know how to prevent } \\
\text { COVID-19 } \\
\text { infection? }\end{array}$} \\
\hline Yes & $177(70.2)$ \\
\hline No & $1(0.4)$ \\
\hline Not fully sure & $71(28.2)$ \\
\hline Cannot be prevented & $3(1.2)$ \\
\hline \multicolumn{2}{|l|}{$\begin{array}{c}\text { What can happen to a person } \\
\text { suffering } \\
\text { from COVID-19? }\end{array}$} \\
\hline $\begin{array}{l}\text { ICU care for those with serious } \\
\text { medical illness }\end{array}$ & $32(12.7)$ \\
\hline Few may need hospitalisation & $12(4.8)$ \\
\hline No treatment maybe required & $2(0.8)$ \\
\hline All of the above & $206(81.7)$ \\
\hline \multicolumn{2}{|l|}{$\begin{array}{l}\text { In which age group, does COVID-19 } \\
\text { spread? }\end{array}$} \\
\hline All age & $239(94.8)$ \\
\hline Children & $1(0.4)$ \\
\hline Elderly & $12(4.8)$ \\
\hline Pregnant & $0(0)$ \\
\hline
\end{tabular}




\begin{tabular}{|c|c|}
\hline $\begin{array}{l}\text { What are the symptoms of } \\
\text { COVID-19? }\end{array}$ & \\
\hline Fever & $1(0.4)$ \\
\hline Cough & $0(0)$ \\
\hline Shortness of breath & $0(0)$ \\
\hline All the above & $251(99.6)$ \\
\hline \multicolumn{2}{|l|}{$\begin{array}{l}\text { Do you know whom to contact if you } \\
\text { show symptoms of COVID-19? }\end{array}$} \\
\hline Yes & $236(93.7)$ \\
\hline No & $16(6.3)$ \\
\hline \multicolumn{2}{|l|}{$\begin{array}{c}\text { Do you know the COVID-19 helpline } \\
\text { number of your state? }\end{array}$} \\
\hline Yes & $197(78.2)$ \\
\hline No & $55(21.8)$ \\
\hline \multicolumn{2}{|l|}{$\begin{array}{l}\text { Where do you think COVID-19 } \\
\text { treatment is available? }\end{array}$} \\
\hline Government hospitals & $40(15.9)$ \\
\hline Private hospitals & $1(0.4)$ \\
\hline Private clinics & $1(0.4)$ \\
\hline 1 and 2 & $210(83.3)$ \\
\hline \multicolumn{2}{|l|}{$\begin{array}{l}\text { Which are the COVID-19 online } \\
\text { tracking applications? }\end{array}$} \\
\hline Worldometer & $5(2.0)$ \\
\hline HealthLynked COVID-19 & $6(2.4)$ \\
\hline GO CORONA GO & $0(0)$ \\
\hline Aarogya Setu & $137(54.4)$ \\
\hline All of the above & $104(41.3)$ \\
\hline \multicolumn{2}{|l|}{$\begin{array}{l}\text { Is there any treatment for } \\
\text { COVID-19? }\end{array}$} \\
\hline Yes & $67(26.6)$ \\
\hline No & $97(38.5)$ \\
\hline Not sure & $88(34.9)$ \\
\hline \multicolumn{2}{|l|}{$\begin{array}{l}\text { Which speciality is vital for } \\
\text { COVID-19? }\end{array}$} \\
\hline Medicine & $160(63.5)$ \\
\hline Surgery & $1(0.4)$ \\
\hline Community medicine & $85(33.7)$ \\
\hline Anaesthesia & $6(2.4)$ \\
\hline \multicolumn{2}{|l|}{$\begin{array}{l}\text { What are the sources of awareness } \\
\text { regarding COVID-19? }\end{array}$} \\
\hline Newspaper & $5(2.0)$ \\
\hline Television & $2(0.8)$ \\
\hline Internet & $8(3.2)$ \\
\hline All of the above & $237(94.0)$ \\
\hline
\end{tabular}

Table 3.Attitude regarding COVID- 19 among Study Participants $(n=252)$

\begin{tabular}{|c|c|}
\hline Attitude & $\begin{array}{c}\text { Frequency } \\
(\%)\end{array}$ \\
\hline $\begin{array}{c}\text { Are you worried that someone you know } \\
\text { may have an infection and you are not } \\
\text { aware of it? }\end{array}$ & \\
\hline Yes & $60(23.8)$ \\
\hline No & $84(33.3)$ \\
\hline Sometimes & 108 (42.9) \\
\hline $\begin{array}{l}\text { What do you feel is the nature of the } \\
\text { disease? }\end{array}$ & \\
\hline Fatal & $26(10.3)$ \\
\hline Mild & $69(27.4)$ \\
\hline Serious & $131(52.0)$ \\
\hline Don't know & $26(10.3)$ \\
\hline $\begin{array}{l}\text { Do you agree with the government's } \\
\text { decision of declaring lockdown? }\end{array}$ & \\
\hline Completely agree & $179(71.0)$ \\
\hline Somewhat agree & $69(27.4)$ \\
\hline Wrong decision & $2(0.8)$ \\
\hline Don't know & $2(0.8)$ \\
\hline $\begin{array}{l}\text { Do you think that the government's } \\
\text { initiatives to prevent COVID- } 19 \text { are } \\
\text { adequate? }\end{array}$ & \\
\hline Yes & $104(41.3)$ \\
\hline No & $97(38.5)$ \\
\hline Don't know & $51(20.2)$ \\
\hline $\begin{array}{l}\text { Do you think the lockdown was helping } \\
\text { in reducing the number of cases? }\end{array}$ & \\
\hline Yes & 202(80.2) \\
\hline No & $32(12.7)$ \\
\hline Don't know & $18(7.1)$ \\
\hline $\begin{array}{l}\text { Do you feel there is a need for another } \\
\text { lockdown so as to reduce new cases of } \\
\text { COVID-19? }\end{array}$ & \\
\hline Yes & $139(55.2)$ \\
\hline No & $70(27.8)$ \\
\hline Don't know & $43(17.1)$ \\
\hline $\begin{array}{c}\text { Do you feel that taking precautions such } \\
\text { as hand washing, isolation, quarantine, } \\
\text { social distancing, and wearing a mask } \\
\text { will reduce the transmission? }\end{array}$ & \\
\hline Yes & 246 (97.6) \\
\hline No & $3(1.2)$ \\
\hline
\end{tabular}




\begin{tabular}{|c|c|}
\hline Don't know & $3(1.2)$ \\
\hline $\begin{array}{l}\text { If you or your close ones are having } \\
\text { COVID-19 symptoms, what will you do? }\end{array}$ & \\
\hline Go to hospital & $68(27.0)$ \\
\hline Treat at home using home remedies & $17(6.7)$ \\
\hline Nothing & $1(0.4)$ \\
\hline Isolate/quarantine & $166(65.9)$ \\
\hline $\begin{array}{l}\text { What do you think is better for COVID-19 } \\
\text { infection suspects? }\end{array}$ & \\
\hline Home quarantine & $134(53.2)$ \\
\hline Administrative quarantine & $60(23.8)$ \\
\hline Isolation & $53(21.0)$ \\
\hline Others & $5(2.0)$ \\
\hline $\begin{array}{c}\text { Do you feel wearing a cotton mask/ } \\
\text { triple-layer mask will protect you from } \\
\text { COVID-19? }\end{array}$ & \\
\hline Yes & $80(31.7)$ \\
\hline No & $28(11.1)$ \\
\hline Maybe & $138(54.8)$ \\
\hline Don't know & $6(2.4)$ \\
\hline $\begin{array}{l}\text { Have you looked for information on how } \\
\text { to wear a mask correctly? }\end{array}$ & \\
\hline Yes, I have & $149(59.1)$ \\
\hline No, I haven't & $20(7.9)$ \\
\hline I know how to & $53(21.0)$ \\
\hline Partially looked for & $30(11.9)$ \\
\hline $\begin{array}{l}\text { Do you think it was difficult to get } \\
\text { essential commodities in your area? }\end{array}$ & \\
\hline Yes & $20(7.9)$ \\
\hline No & $161(63.9)$ \\
\hline Sometimes & $65(25.8)$ \\
\hline Don't know & $6(2.4)$ \\
\hline
\end{tabular}

Table 4.Practices regarding COVID- 19 among Study Participants $(n=252)$

\begin{tabular}{|c|c|}
\hline Practice & Frequency (\%) \\
\hline \multicolumn{2}{|l|}{$\begin{array}{c}\text { Do you wash your hands with soap } \\
\text { and water regularly? }\end{array}$} \\
\hline Yes & $214(84.9)$ \\
\hline No & $2(0.8)$ \\
\hline Sometimes & $36(14.3)$ \\
\hline \multicolumn{2}{|l|}{$\begin{array}{c}\text { Are you wearing a mask to avoid } \\
\text { transmission? }\end{array}$} \\
\hline Yes & $249(98.8)$ \\
\hline Sometimes & $3(1.2)$ \\
\hline \multicolumn{2}{|l|}{$\begin{array}{l}\text { Are you following the guidelines } \\
\text { given by the authority for lockdown? }\end{array}$} \\
\hline Completely follow & $205(81.3)$ \\
\hline Somewhat follow & $46(18.3)$ \\
\hline Don't know & $1(0.4)$ \\
\hline \multicolumn{2}{|l|}{$\begin{array}{l}\text { Have you been maintaining social } \\
\text { distancing? }\end{array}$} \\
\hline Yes & $226(89.7)$ \\
\hline No & $1(0.4)$ \\
\hline Sometimes & $25(9.9)$ \\
\hline \multicolumn{2}{|l|}{$\begin{array}{c}\text { Do you keep a track of the trend, the } \\
\text { disease is taking? }\end{array}$} \\
\hline Yes & $148(58.7)$ \\
\hline No & $24(9.5)$ \\
\hline Sometimes & $79(31.3)$ \\
\hline Don't remember & $1(0.4)$ \\
\hline \multicolumn{2}{|l|}{$\begin{array}{l}\text { What did you prefer to do in } \\
\text { lockdown? }\end{array}$} \\
\hline Stayed at home & $247(98.0)$ \\
\hline Went to work & $5(2.0)$ \\
\hline \multicolumn{2}{|l|}{$\begin{array}{l}\text { How did you spend your time during } \\
\text { lockdown? }\end{array}$} \\
\hline Sleep & $34(13.5)$ \\
\hline Went to work & $2(0.8)$ \\
\hline New hobby & $81(32.1)$ \\
\hline Played games online & $51(20.2)$ \\
\hline Worked from home & $84(33.3)$ \\
\hline \multicolumn{2}{|l|}{$\begin{array}{l}\text { Did you keep any food reserve at } \\
\text { home during lockdown, and for how } \\
\text { many days? }\end{array}$} \\
\hline 1-3 days & $87(34.5)$ \\
\hline 1 week & $119(47.2)$ \\
\hline
\end{tabular}

\section{Attitudes towards COVID-I9 among the Participants}

A total of 131 respondents (52\%) reported that COVID-19 is a serious disease, and $179(71 \%)$ responded that they fully agreed with the decision made by the government regarding lockdown.104 participants $(41.3 \%)$ considered the initiatives taken by the administration as adequate and 202 (80.2\%) respondents acknowledged that the lockdown was instrumental in reducing the number of cases. 139 (55.2\%) individuals felt the need for another lockdown to reduce the case load, and 246 (97.6\%) believed that hand washing, wearing masks, social distancing, and quarantine/ isolation are effective strategies to reduce transmission (Table 3). 


\begin{tabular}{|c|c|}
\hline 1 month & $45(17.9)$ \\
\hline 1 year & $1(0.4)$ \\
\hline $\begin{array}{c}\text { Did your family take/ receive any } \\
\text { support from the government during } \\
\text { the lockdown period? }\end{array}$ & $70(27.8)$ \\
\hline Yes & $118(46.8)$ \\
\hline No & $55(21.8)$ \\
\hline Not aware & $9(3.6)$ \\
\hline Don't want to & $151(59.9)$ \\
\hline $\begin{array}{c}\text { What would have been your plans if } \\
\text { this lockdown had continued? }\end{array}$ & $34(13.5)$ \\
\hline No plans & $6(2.4)$ \\
\hline Support from government & $3(1.2)$ \\
\hline Selling assets & $58(23)$ \\
\hline Taking credit & \\
\hline Not applicable &
\end{tabular}

\section{Practices related to COVID-I9 among the Respondents}

Among the participants, 249(98.8\%) wore masks to prevent disease transmission, and 214 (84.9\%) individuals regularly washed their hands with soap and water. 226(89.7\%) respondents practised social distancing norms, 205(81.3\%) individuals adhered to the guidelines issued by the authorities for the lockdown, and 247 (98\%) participants preferred to stay at home during lockdown (Table 4).

\section{Discussion}

To the best of our knowledge this is the first study on knowledge, attitude and practices regarding COVID-19 conducted among non-healthcare related college-students in the southern state of Kerala. We received completed responses from 252 participants within 4 days of circulation of the questionnaire. Most of the participants (62.7\%) were between 18 and 40 years of age as the study was conducted among engineering college students. Regarding knowledge about COVID-19, majority of the participants gained information about COVID-19 through social media (59.5\%) rather than the traditional sources like televisions and newspapers. This could be because our target population who were young adults, were the most active population on social media platforms. This is similar to a study conducted in Jammu and Kashmir where $61 \%$ of the respondents gained knowledge of COVID-19 through social media. ${ }^{9}$ Almost all participants were aware of the symptoms of COVID-19 (99.6\%) and majority of them (96.4\%) knew all modes of transmission of the virus. Singh et al conducted a study involving 529 university students in India and reported that $91 \%$ knew about the symptoms of the illness while
$68 \%$ had awareness about the modes of transmission from one person to another. ${ }^{10} \mathrm{~A}$ study conducted in South Korea among 970 subjects by Lee et al observed that 85.1 $\%$ of the participants had knowledge about the symptoms of COVID-19 while $93.2 \%$ knew about the transmission modes. ${ }^{11}$ The higher levels of knowledge with regards to symptoms and method of transmission in the current study could be due to the fact that the participants were social media users and this information is easily available on online platforms. However, only a few of them (38.5\%) were aware that there is no definite treatment for the same, whereas in a similar study conducted in Bangladesh, 80.7\% of respondents were aware that there is only supportive treatment for COVID-19 infection. ${ }^{12}$ Even though the study was conducted among non-healthcare related college students, a good percentage of them $(63.5 \%)$ knew that Medicine is the vital-specialty for COVID-19. More than half of the respondents (54.4\%) knew only about Aarogya sethu app as an online COVID-19 tracking application which could be attributed to the government encouraging individuals to use this indigenously developed app.

Regarding the attitude towards COVID-19, only $10 \%$ of the participants considered it as a fatal disease and $23.8 \%$ of them were worried that someone they knew may contract the infection and maybe asymptomatic. In a similar study conducted during the initial months of the spread of this disease in India, 39\% of the respondents considered it a fatal disease and $36 \%$ of them were worried that someone they knew may have an infection. ${ }^{9}$ The worry factor might have reduced in the population over the months owing to increasing awareness of better recovery rates. $71 \%$ of the participants completely agreed with the government's decision of declaring lockdown, which is similar to an earlier study where $78 \%$ of the respondents were in agreement with this decision. ${ }^{9} 55.2 \%$ of the participants felt a need for another lockdown to reduce new cases of COVID-19. Some participants reported having to face difficulties during the lockdown.7.9\% of the respondents found it difficult to get essential commodities in their locality, $68.7 \%$ reported that their studies had been affected and $57.9 \%$ had their family's monthly income affected due to lockdown. About 13.5\% of the study subjects would have relied on government support, while $2.4 \%$ were planning to sell assets and $1.2 \%$ were planning to take credits if lockdown had continued.

On evaluating the practices towards COVID-19, $84.9 \%$ of the participants regularly washed their hands with soap and water whereas, a similar study conducted among university students of the United Arab Emirates reported that $99.4 \%$ of their participants used soap and water for handwashing. ${ }^{13}$ In our study $98.8 \%$ of the participants used face masks to avoid transmission of the disease, while in an earlier study, only $90.4 \%$ of the respondents 
used a face mask. ${ }^{13} \mathrm{~A}$ large multinational survey involving 71890 participants from across 22 nations observed that $82 \%$ of the participants reported that they wore a face mask in crowded places, however only $52 \%$ wore a mask when they step out in general especially to places that are not crowded. ${ }^{12} 81.3 \%$ of our participants reported that they followed guidelines from the government related to COVID-19, which is similar to an earlier study where $88.4 \%$ of the participants obeyed all government rules. ${ }^{12}$ Majority of the participants (89.7\%) in our study maintained social distancing, whereas a similar study reported that $95.4 \%$ of their participants practised social distancing. ${ }^{13}$ An online cross-sectional survey conducted in Yemen among 1231 individuals noted that $87.7 \%$ of the respondents reported adherence to preventive behaviours, which is in alignment with our study findings. ${ }^{14}$ Most of the participants (98\%) preferred to stay at home during the lockdown; $13.5 \%$ spent their time sleeping, and $20.2 \%$ spent it by playing online games. This indicates a lack of physical activity in these young individuals, which can prove detrimental if continued for an extended period of time. ${ }^{15}$

\section{Limitations}

This study has some limitations. Since this is a cross sectional study, causal inferences may not be established. Also, since it employs a self-reported questionnaire study, it would be subject to bias.

\section{Conclusion}

Our findings suggest that respondents in this study, who were social media users among non-healthcare related college-going students from Kerala, displayed good knowledge, positive attitude and followed responsible practices related to COVID-19 as compared to other studies from India and across the world. This study points to the role of continued health education programmes, especially on social media in ensuring that the public follows safe and informed practices to keep this pandemic in check. Further studies on knowledge, attitude and practices among specific subgroups in the society are essential to identify the gaps in knowledge and patterns of behaviour, which need to be addressed through tailored interventions.

\section{Acknowledgement}

The authors are very thankful to all the respondents who took part in the study.

\section{Sources of Funding: None \\ Conflict of Interest: None}

\section{References}

1. Mackenzie JS, Smith DW. COVID-19: a novel zoonotic disease caused by a coronavirus from China: what we know and what we don't. Microbiol Aust. 2020;41(1):45.
[PubMed] [Google Scholar]

2. Kumar S, Singh R, Kumari N, Karmakar S, Behera M, Siddiqui AJ, Rajput VD, Minkina T, Bauddh K, Kumar N. Current understanding of the influence of environmental factors on SARS-CoV-2 transmission, persistence, and infectivity. Environ Sci Pollut Res. 2021 Feb;28(6):6267-88. [PubMed] [Google Scholar]

3. Worldometer [Internet]. COVID Live Update: 174,654,044 Cases and 3,759,793 Deaths from the Coronavirus; [cited 2021 Jun 9]. Available from: https:// www.worldometers.info/coronavirus/

4. Menon JC, Rakesh PS, John D, Thachathodiyl R, Banerjee A. What was right about Kerala's response to the COVID-19 pandemic? BMJ Glob Health. 2020 Jul;5(7):e003212. [PubMed] [Google Scholar]

5. Kerala State Disaster Management Authority [Internet]. 2021 [cited 2021 Feb 24]. Available from: https://sdma. kerala.gov.in

6. Bhagavathula AS, Aldhaleei WA, Rahmani J, Mahabadi MA, Bandari DK. Knowledge and Perceptions of COVID-19 Among Health Care Workers: CrossSectional Study. JMIR Public Health Surveill. 2020 Apr 30;6(2):e19160. [PubMed] [Google Scholar]

7. Al-Hanawi MK, Angawi K, Alshareef N, Qattan AM, Helmy HZ, Abudawood Y, Alqurashi M, Kattan WM, Kadasah NA, Chirwa GC, Alsharqi O. Knowledge, Attitude and Practice Toward COVID-19 Among the Public in the Kingdom of Saudi Arabia: A Cross-Sectional Study. Front Public Health. 2020 May 27;8:217. [PubMed] [Google Scholar]

8. Azlan AA, Hamzah MR, Sern TJ, Ayub SH, Mohamad E. Public knowledge, attitudes and practices towards COVID-19: A cross-sectional study in Malaysia. PLoS One. 2020 May 21;15(5):e0233668. [PubMed] [Google Scholar]

9. Dkhar SA, Quansar R, Saleem SM, Khan SM. Knowledge, attitude, and practices related to COVID-19 pandemic among social media users in J\&K, India. Indian J Public Health. 2020;64(6):205. [PubMed] [Google Scholar]

10. Singh JP, Sewda A, Shiv DG. Assessing the Knowledge, Attitude and Practices of Students Regarding the COVID-19 Pandemic. J Health Manag. 2020 Jun;22(2):281-90. [Google Scholar]

11. Lee M, Kang B-A, You M. Knowledge, attitudes, and practices (KAP) toward COVID-19: a cross-sectional study in South Korea. BMC Public Health. 2021 Feb;21(1):295. [PubMed] [Google Scholar]

12. Ferdous MZ, Islam MS, Sikder MT, Mosaddek AS, Zegarra-Valdivia JA, Gozal D. Knowledge, attitude, and practice regarding COVID-19 outbreak in Bangladesh: An online-based cross-sectional study. PloS One. 2020;15(10):e0239254. [PubMed] [Google Scholar]

13. Hasan H, Raigangar V, Osaili T, Neinavaei NE, Olaimat 
AN, Aolymat I. A Cross-Sectional Study on University Students' Knowledge, Attitudes, and Practices Toward COVID-19 in the United Arab Emirates. Am J Trop Med Hyg. 2021 Jan 6;104(1):75-84. [PubMed] [Google Scholar]

14. Alrubaiee GG, Al-Qalah TA, Al-Aawar MS. Knowledge, attitudes, anxiety, and preventive behaviours towards COVID-19 among health care providers in Yemen: an online cross-sectional survey. BMC Public Health. 2020 Oct;20(1):1541. [PubMed] [Google Scholar]

15. Füzéki E, Groneberg DA, Banzer W. Physical activity during COVID-19 induced lockdown: recommendations. J Occup Med Toxicol. 2020 Aug;15(1):25. [PubMed] [Google Scholar] 